\title{
The Effectiveness of the Blended Learning in Enhancing EFL Learning and Collaboration
}

\author{
Faiza Abdalla Elhussien Mohamed ${ }^{1,2}$ \\ ${ }^{1}$ Zulfi College of Education, Majmaah University, Saudi Arabia \\ ${ }^{2}$ Omdurman Islamic University, Sudan \\ Correspondence: Faiza Abdalla Elhussien Mohamed, Saudi Arabia, P.O. Box: 1221 Zulfi 11932, Saudi Arabia.
}

Received: November 9, 2021

Accepted: December 16, $2021 \quad$ Online Published: December 23, 2021

doi:10.5430/wjel.v12n1p92

URL: https://doi.org/10.5430/wjel.v12n1p92

\begin{abstract}
This descriptive-analytical study investigates undergraduates' perceptions and reflections toward adopting the Blended-Learning system in the university instructions. For this goal, the study employed two tools to collect data. Firstly, a) ( $n=38)$ pre-service teachers wrote reflection essays, and b) Google forms closed-ended five scales' questionnaire investigated the academic and interaction indicators, each consisting of thirty items, distributed among $(n=110)$ pre-service teachers. The participants were majoring in English as a Foreign language at multi-stages, Saudi Arabia, 2020/2021. The study employed the content and the SPSS analysis. The questionnaire's results showed the undergraduates' positive perceptions toward combining online and face-to-face learning and how this environment improved their learning outcomes, created a collaborative community, fostered openness for sharing, asking, expressing, and getting talk-worthy ideas. The essays' content analysis reflected the undergraduates' experiences and how they enjoyed transitioning between online and face-to-face learning; they were satisfied by the ability to track their scores. These results created a continuous feedback loop correlated with their academic progress through various activities. However, they encountered a few challenges in online classes like a) missed face-to-face warm environment, b) lost attention, and c) missed instructors' nonverbal cues. Generalized, blended learning facilitated learners' knowledge by reducing education costs, distance, efforts, and time without reducing the students' benefits. The study recommends that the BL instructors have to show some enthusiasm and inspiration. The study proposes future research.
\end{abstract}

Keywords: Blended-learning (BL), blended learning assessment, traditional vs. blended learning, pre-service teachers, and collaboration

\section{Introduction}

Technology has gained an essential part in creating people's intelligent life that revealed through recent research intriguing findings. It highlights all human aspects of life from business, communication, science, and social interaction worldwide. Education, in general, is one of these dimensions, especially in teaching and learning a foreign language to EFL students, online education, in particular, has not only changed the geography of distance education but has significantly impacted advanced education as a whole across the globe. According to Tomlison \& Whittaker (2013), blended learning aims to recognize the maximum mix of course delivery to maintain the most effective language learning outcomes. Education institutions have profited from advanced education, the commercialization of education, and the increasing demand for online education (Allen \& Seaman, 2011). Blended learning is a transformational concept that intends to sustain collaborative learning; constructive learning and computer-assisted learning both offline learning and online learning (Lalima \& Dangwal, 2017)

The world advancement is currently witnessing computers, communication technology, and smartphones with internet power a decade ago, besides the help of some learning management systems such as Desire2Learn, Blackboard, Moodle. The essential change in future e-learning environments depends on removing the administrative portions of an LMS to create an e-learning environment that mainly focuses on learning (Jobe, 2011). The appropriate program to be developed is blended learning based on these learning models. Blended learning's tools facilitate what teachers do in the traditional classrooms by the aid of the various types of platforms give a chance to create content, schedule classes, records lessons; it can also provide social interaction facilities as virtual discussion rooms (Siregar et al., 2019) 
Some studies, however, have explored how pre-service teachers can reflect their experiences' growth and development. Exploring these experiences is potentially significant because the researcher observed that some of them are unwilling and unenthusiastic to study through blended learning rather than the traditional learning, saying, "Why to try something new since what I am doing is working well," as claimed by (Tucker, 2019).

In this qualitative and quantitative study, the researcher sought to address these gaps by addressing three questions that guided the study:

1. What were the Blended learning benefits on the English-major pre-service teachers' academic performance?

2. How did English-major pre-service teachers evaluate the Blended learning environment's effectiveness on their engagement and interaction?

3. What were the obstacles did the English- major pre-service teachers face in the blended learning courses?

\section{The Significance}

The outcomes from this study will be of significant benefits to the following:

\section{Colleges}

Data given will provide colleges with information about the impact of blended learning on the students' academic progress. These results enable them to accelerate the adoption of more blended learning courses among their educational programs, solve the obstacles faced by the participants and reduce the students' dropping out rates.

\section{Instructors}

Not only do college or students have access to more collaboration through blended learning, as claimed by Schaber et al. (2010), but teachers also need to collaborate frequently with their colleagues to maintain and improve their practice in a blended learning environment. Moreover, the results will help instructors evaluate the quality of the blended learning's roles in advancing their students' academic performance and attitudes to develop the strategies of instructions.

\section{Students}

The study results will encourage and create space for students to engage deeply in collaborative blended works and to foster new ways for enhancing their knowledge, skills. They can develop and improve their learning responsibilities, gain more digital competence systems through blended systems various tools, and develop better practice using the blended learning tools for mastering, managing, and engaging.

\section{The Objectives}

The research aimed to:

1. Explore and assess pre-service teachers' perceptions and reflections toward the effectiveness of the blended-learning on their academics' performance.

2. Investigate pre-service teachers' knowledge about the facilities, forms of instruction, and blended learning interaction to support their learning.

3. Explore the benefits of the BL environment and its roles in increasing the participants' interactions.

4. Identify the fundamental challenges faced by the participants during the blended classes, and suggest solutions

\section{Background}

Blended Learning

Blended learning is one of the current directions in education. It supports detailed information about a successful program's strategy, design, and implementation (Michael, Staker \& Clayton (2014). Tucker (2019, p. 2) defined blended learning as a combination of online learning with learning in the physical classroom. According to Lim et al. (2017, p. 263), shifting to blended learning requires a significant shift in learning and teaching practice, redefining the role of the teaching staff members and students and scrutinizing the responsibility for learning. Bowyer (2017, P.16) claimed that blended learning adoption improves the course outcomes of the students' retention, pass-rate, improve attainment autonomy, and responsibility towards their education. Kitchenham (2011, p. xiv) explained why hybrid learning has proven to be the most popular choice for students at institutions because of its role in blending some aspects of technology with face-to-face learning. Tucker et al. (2016) defined blended learning as a new formal educational program with elements that help students control their time, place, and pace. Innes, Norman \& 
Garrison. (2013, p. 25) stated that the blended learning environment considers a social interaction that sets the environmental conditions in higher education for open cohesion, communication, and interpersonal connection.

\section{Learning Assessment}

Blended learning assessment helps teachers build comfortable environments to motivate learners to interact and allow teachers to observe students' progress. Moreover, to modify instructions to maximize learning outcomes. According to Koc, Lui \& Wachira (2015, p 188,) and OECD (2016, P. 9), software, such as Management Learning Systems (MLS), scaffolds blended learning in its job, which defines as "software that offers various ways for assessment such as rubric, quizzes, exams, and discussion. It can assess using:

\section{Traditional vs. Blended Learning}

Traditional teachers lead, instruct, control the learning environment, and use the traditional grading system in the conventional learning process. While in the blended learning system, the students are its center and involved in paced learning (Tucker $(2019$, p.5). The aims of transitioning from traditional education to blended learning, as stated by (Tucker et al.,2016, p. 67), are to personalize learning from a teacher- as- driver to student- driver. The students drive their knowledge and become primary stakeholders in their education. Teachers help students set their learning self-discipline and goals, seek valuable resources, and build pathways to create learning outcomes.

\section{Pre-Service Teachers}

Pre-service teachers are university undergraduates enrolled in a teacher education program. It enables them to get involved in practical teaching experience under the guidance of a senior teacher. In this experience, the pre-service teachers are progressively trained to be responsible for managing classroom. They are prepared for future professional-level teaching positions Marquardt (2011)..

\section{Collaboration}

According to Garrison (2005), the objective of the collaboration is to build a community in which learners are entirely engaged in collaboratively constructing and meaningful knowledge. Studies show that collaboration in learning helps students work together creatively, away from traditional education learning experience through work with one another (Glassmeyer, Dibbs, \& Jensen, 2011).

Liu (2007) indicates that an association occurs betwixt the sense of learning community and the perceived learning outcomes and quality. There is abundant confirmation that blended learning innovates strategies consolidating cognitive and practical competence. It consists of studies indicated that the undergraduates' motivation was developed, displayed deeper understanding and more remembering when asked to resolve problems, and built knowledge from their experiences both in and outside the classroom (Hancock et al., 2010)

Ja'ashan (2015) argues the problem that annoys Bisha University level eight male and female students towards Blended English language courses. The survey results revealed that blended learning is as active as face-to-face learning in developing and improving knowledge and skill. On the other hand, the current research results opposed the results of Nazarnkoa (2015) concerning traditional vs. blending learning in which the researcher distributed two electronic Monkey surveys among sixty- two undergraduates' students. They compared the new features of the blended learning course in its new format with a traditional one; most of the students' responses $(96 \%)$ are favorable toward the course's blended format with few unfavorable impressions as it wastes time and is easy to cheat.

In contrast to the above study, Baeer (2018) conducted a case study concerning Blended Learning to improve ( $\mathrm{n}=60$ ) of Al Guds Open University students. The findings showed that blended learning affects positively on the undergraduates' language skills and autonomous learning and motivation. As a result, the study recommends strengthening blended learning to enrich students' knowledge, language skills, and proficiency.

Albiladi \& Khlod (2019) from Saudi Arabia carried out a study review, discuss, and examine some research that integrates blended learning in EFL and ESL contexts and the educational and interaction merit of this procedure. The study showed that blended learning can capably develop language competence, scaffold the language learning environment, and support students' inspiration to learn the language.

Fathelrahman's (2018) study intended to review and document literature and practices related to the different ways to collect feedback from students. It follows the socio-technical approach to management systems and reflective model during distance education courses; the findings indicated that reflecting on the students' feedback could improve the teaching quality of distance learning.

Moreover, Okaz (2015, p.1) discussed the pros and cons of integrating blended learning if the instructors incorporate 
blended learning in higher education and provide some hands-on experience and classroom activities to create student-centered and collaborative learning environment.

Furthermore, Akbarvo, Gonen, and Haken (2018, p. 2) investigated a hundred and sixty-two students' attitudes towards blended learning and related concepts as a paperless and traditional classroom. The students preferred blended learning to face-to-face, but they chose to have exams in paper and pen form. They trust digital learning materials and link their English language proficiency with combined education.

Wei et al., (2017) explored the effectiveness of mixed learning methods on the experimental and control groups of a hundred and four undergraduates' performance and press, they found that the undergraduates who taught through blended learning got the topmost scores than students taught with the conventional methods, but no noteworthy variation in students' academic press between both methods.

Many studies examined the Blended Learning approach's impact on EFL students' educational goals and the degree of satisfaction. The present study explores and assesses blended learning tools and environments that influence the participants" academic performance concerning Miller's (2014, p. 19) question about integrating technology in learning: Does technology degrade or improve understanding or have no natural effect at all? The majority of responses revealed that blended learning positively helped the participants to involve in different coactively or independent learning environments, understand, and be confident enough to address and solve the problems encountered in their academic progress.

The difference between this study and the previous studies was that the last one investigated the learners' perceptions of integrating blended learning in the learning process using closed-ended tools. In contrast, this study gets the participants' reflection through uncontrolled devices (essays) to reach results and answer the questions about the benefits and obstacles of Blended learning and its environment on their academic and collaboration performance3.

\section{Research Methodology}

This case study uses a mixed-method to explore the blended learning benefits and challenges from the pre-service teachers' perceptions and reflections. The study designed tools to suit the present study scope, objectives and answer the study questions; based on this understanding, the methodology outlined as follows:

\section{Participants}

Two groups ( $\mathrm{n}=148$ ) of English- major pre-service teachers at the English language Education program, Majmaah /University, KSA. were involved in the study. They were divided into a) purposive sampling group of thirty-eight $(\mathrm{n}=$ $38)$, at level five, $b$ ) hundred-ten $(n=110)$ from varied levels enrolled in many blended learning course.

\section{Study Tools}

The study employed two tools:

\section{Tool 1: A Quantitative Tool}

An electronic closed-ended questionnaire, as suggested by Tang and Chaw (2013, p. 83), consisted of two indicators: a) academic indicators (cognitive and knowledge) of twenty statements, and b) the environmental indicators (engagement, collaboration, and interaction), of thirteen statements.

\section{Tool 2: Qualitative Tool}

A purposive group ( $\mathrm{n}=38$ ) wrote reflection essays about The role of Virtual Classes on the Students' Academics' Success" to express their opinions and knowledge about the blended learning benefits and challenges. (Taylor, Bogdan, \& De Vault (2016, p. 10)

\section{Data Collection Procedures}

The researcher sends a google forms questionnaire's link through the blackboard announcement to the mixed-level English- major pre-service teachers (received only 110 responses) within four weeks. Thirty-eight submit their performative essays to the Blackboard dropbox within two weeks. The complete study preparation and implementation were carried out during COVID-19 Lock-down in the academic year 2020- 2021.

\section{The Validity and Reliability}

The juries proved the questionnaire's overall accuracy. In terms of validity. They asserted that it covered all the research questions in a systematically relevant fashion way, and stated a consistency between the theoretical concepts and the proposed measurement tools.

Statistically, as claimed by the traditional test theorists, the most test's validity is the square of the reliability; hence, the Published by Sciedu Press 
subjective validity value of the questionnaire statements is as follow:

Table 1. The Questionnaire statements' validity and reliability

\begin{tabular}{|l|l|c|c|c|}
\hline No & \multicolumn{1}{|c|}{ Dimensions } & No. of Statements & Coefficient of alpha-Cronbach & Validity \\
\hline 1 & The first Question & 20 & 0.933 & 0.870 \\
\hline 2 & The second Question & 13 & 0.926 & 0.857 \\
\hline
\end{tabular}

Source: Prepared by the researcher from data (2020)

The above table 1 indicated that the constancy (Alpha-Cronbach coefficient) of the statements that answered the first question was (0.933), while the second question reached $(0.926)$, which will give the same findings if it uses again in the same condition.

Moreover, the validity of the questionnaire's academic and environmental indicators is $(0.87 \%)$ and $(0.85)$ respectively, which means that the questionnaire is valid for measuring the students' perceptions towards the blended learning benefits and obstacles.

\section{Results}

The results obtained from the quantitative and qualitative data were organized under the academic and environmental indicators as follow:

\subsection{Quantitative Results from the Questionnaire}

\subsubsection{Academic indicators' Results}

The following Tables 2 and 3 show the frequency distribution and percentage of the first indicator's statements that answered the study's first question: What were the blended learning benefits on the English-major pre-service teachers' academic performance?

Table 2. Descriptive Statistics for the academic indicators' statements from (1-10)

\begin{tabular}{|c|c|c|c|c|c|c|}
\hline Statements & & $\begin{array}{c}\text { Strongly } \\
\text { agree }\end{array}$ & Agree & Neutral & Disagree & $\begin{array}{l}\text { Strongly } \\
\text { disagree }\end{array}$ \\
\hline \multirow{2}{*}{$\begin{array}{l}\text { 1. Blended learning eased my access to the course } \\
\text { materials. }\end{array}$} & $\mathrm{F}$ & 25 & 51 & 25 & 7 & 2 \\
\hline & $\%$ & 22.7 & 46.4 & 22.7 & 6.4 & 1.8 \\
\hline \multirow{2}{*}{$\begin{array}{l}\text { 2. Blended learning, supported my intellectual, } \\
\text { technical capacity. }\end{array}$} & $\mathrm{F}$ & 22 & 53 & 29 & 5 & 1 \\
\hline & $\%$ & 20 & 48.4 & 26.4 & 4.5 & 0.9 \\
\hline \multirow{2}{*}{$\begin{array}{l}\text { 3. Online classrooms were as active as traditional } \\
\text { ones. }\end{array}$} & $\mathrm{F}$ & 11 & 45 & 36 & 13 & 5 \\
\hline & $\%$ & 10 & 40.9 & 32.7 & 11.8 & 4.5 \\
\hline \multirow{2}{*}{$\begin{array}{l}\text { 4. I got the technical support I need during BL } \\
\text { courses. }\end{array}$} & $\mathrm{F}$ & 15 & 52 & 33 & 8 & 2 \\
\hline & $\%$ & 13.6 & 47.3 & 30 & 7.3 & 1.8 \\
\hline \multirow{2}{*}{$\begin{array}{l}\text { 5. Blended learning improved my academic } \\
\text { achievement, and I scored high marks. }\end{array}$} & $\mathrm{F}$ & 21 & 51 & 29 & 6 & 3 \\
\hline & $\%$ & 19.1 & 46.4 & 26.4 & 5.5 & 2.7 \\
\hline \multirow{2}{*}{$\begin{array}{l}\text { 6. Blended learning helped me download and } \\
\text { upload the courses materials. }\end{array}$} & $\mathrm{F}$ & 21 & 46 & 36 & 7 & - \\
\hline & $\%$ & 19.1 & 41.8 & 32.7 & 6.4 & - \\
\hline \multirow{2}{*}{$\begin{array}{l}\text { 7. Blended courses were the only option that fitted } \\
\text { my schedule. }\end{array}$} & $\mathrm{F}$ & 13 & 39 & 42 & 14 & 2 \\
\hline & $\%$ & 11.8 & 35.5 & 38.2 & 12.7 & 1.8 \\
\hline \multirow{2}{*}{ 8. It was challenging to take BL courses. } & $\mathrm{F}$ & 10 & 38 & 42 & 14 & 6 \\
\hline & $\%$ & 9.1 & 34.5 & 38.2 & 12.7 & 5.5 \\
\hline \multirow{2}{*}{$\begin{array}{l}\text { 9. Blended learning courses improved my four } \\
\text { language skills reading, writing, listening, and } \\
\text { speaking. }\end{array}$} & $\mathrm{F}$ & 14 & 40 & 36 & 15 & 5 \\
\hline & $\%$ & 12.7 & 36.4 & 32.7 & 13.6 & 4.5 \\
\hline \multirow{2}{*}{$\begin{array}{l}\text { 10. I hope the university adds more English BL } \\
\text { courses. }\end{array}$} & $\mathrm{F}$ & 19 & 39 & 34 & 16 & 2 \\
\hline & $\%$ & 17.3 & 35.5 & 30.9 & 14.5 & 1.8 \\
\hline
\end{tabular}

Table 2 shows the percentages of the first indicators' statements:

1. The first statement: $(69.1 \%)$ of the respondents agreed with it, and $(22.7 \%)$ were neutral. In contrast, $(8.2 \%)$ respondents disagreed with this statement.

2. The second statement: $(68.4 \%)$ respondents agree with it, and (26.4\%) were neutral. In contrast, (5.4\%) respondents disagreed with this statement.

3. The third statement: $(50.9 \%)$ of the respondents agree with it, and (32.7\%) were neutral. In comparison, $(16.3 \%)$ respondents disagreed with this statement.

4. The fourth statement: $(60.9 \%)$ respondents agree with it, and (30.0\%) were neutral. In comparison, (6.4\%) respondents disagreed with this statement. 
5. The fifth statement: $(65.5 \%)$ respondents agree with it, and $(26.4 \%)$ were neutral. In contrast, $(8.2 \%)$ respondents disagreed with this statement.

6. The sixth statement: $(60.9 \%)$ respondents agree with it, and $(32.7 \%)$ were neutral. In contrast, $(6.4 \%)$ respondents disagreed with this statement.

7. The seventh statement: $(47.2 \%)$ respondents agreed with it, and (38.2\%) were neutral. Simultaneously, $(14.5 \%)$ respondents disagree and strongly disagree with this statement.

8. The eighth statement: (43.6\%) of the respondents agree with it, and (38.2\%) were neutral. In contrast, (18.2\%) respondents disagreed with this statement.

9. The ninth statement: $(49.1 \%)$ of the respondents agree with it, and (32.7\%) were neutral. In comparison, $(18.1 \%)$ respondents disagreed with this statement.

10. The tenth statement: (52.8\%) of the respondents agree with it, and (30.9\%) are neutral. In contrast, (16.3\%) respondents disagreed with this statement.

Table 3. Descriptive Statistics for the academic indicators' statements from (11- 20)

\begin{tabular}{|c|c|c|c|c|c|c|}
\hline Statements & & $\begin{array}{l}\text { Strongly } \\
\text { agree }\end{array}$ & Agree & Neutral & Disagree & $\begin{array}{l}\text { Strongly } \\
\text { disagree }\end{array}$ \\
\hline \multirow{2}{*}{$\begin{array}{l}\text { 11. Blended learning instant feedback helped me in } \\
\text { correcting assignments. }\end{array}$} & $\mathrm{F}$ & 16 & 49 & 35 & 9 & 1 \\
\hline & $\%$ & 14.5 & 44.5 & 31.8 & 8.2 & 0.9 \\
\hline \multirow{2}{*}{$\begin{array}{l}\text { 12. I was adequately introduced to the complete } \\
\text { courses' instructions. }\end{array}$} & $\mathrm{F}$ & 14 & 49 & 36 & 9 & 2 \\
\hline & $\%$ & 12.7 & 44.5 & 32.7 & 8.2 & 1.8 \\
\hline \multirow{2}{*}{$\begin{array}{l}\text { 13. Sometimes it was difficult for me to attend } \\
\text { face-to-face classes. }\end{array}$} & $\mathrm{F}$ & 9 & 35 & 37 & 23 & 6 \\
\hline & $\%$ & 8.2 & 31.8 & 33.6 & 20.9 & 5.5 \\
\hline \multirow{2}{*}{$\begin{array}{l}\text { 14. Blended learning assisted and assessed my } \\
\text { inputs, unlike the traditional classroom. }\end{array}$} & $\mathrm{F}$ & 15 & 39 & 38 & 16 & 2 \\
\hline & $\%$ & 13.6 & 35.5 & 34.5 & 14.5 & 1.8 \\
\hline \multirow{2}{*}{$\begin{array}{l}\text { 15. Adopting blended learning to learn a foreign } \\
\text { language is not a good idea. }\end{array}$} & $\mathrm{F}$ & 10 & 43 & 38 & 16 & 3 \\
\hline & $\%$ & 9.1 & 39.1 & 34.5 & 14.5 & 2.7 \\
\hline \multirow{2}{*}{ 16. Blended Learning eased my learning. } & $\mathrm{F}$ & 22 & 44 & 37 & 5 & 2 \\
\hline & $\%$ & 20 & 40 & 33.6 & 4.5 & 1.8 \\
\hline \multirow{2}{*}{ 17. I feel comfort in Face-to-face interaction } & $\mathrm{F}$ & 27 & 41 & 35 & 5 & 2 \\
\hline & $\%$ & 24.5 & 37.3 & 31.8 & 4.5 & 1.8 \\
\hline \multirow{2}{*}{$\begin{array}{l}\text { 18. Blended learning helped me to be more } \\
\text { productive and more successful }\end{array}$} & $\mathrm{F}$ & 12 & 49 & 33 & 13 & 3 \\
\hline & $\%$ & 10.9 & 44.5 & 30 & 11.8 & 2.7 \\
\hline \multirow{2}{*}{$\begin{array}{l}\text { 19. In blended learning classes, teachers could } \\
\text { easily follow my progress }\end{array}$} & $\mathrm{F}$ & 12 & 44 & 41 & 9 & 4 \\
\hline & $\%$ & 10.9 & 40 & 37.3 & 8.2 & 3.6 \\
\hline \multirow{2}{*}{$\begin{array}{l}\text { 20. Blended learning courses' materials were } \\
\text { available to download on smartphones, tablets, } \\
\text { and desktops whenever I need them }\end{array}$} & $\mathrm{F}$ & 24 & 46 & 31 & 6 & 3 \\
\hline & $\%$ & 21.8 & 41.8 & 28.2 & 5.5 & 2.7 \\
\hline \multirow{2}{*}{$\begin{array}{l}\text { Q1:What were the blended learning benefits on the } \\
\text { English-major pre-service teachers' academic } \\
\text { performance? }\end{array}$} & $\mathrm{F}$ & 332 & 893 & 703 & 216 & 56 \\
\hline & $\%$ & 15.1 & 40.6 & 32.0 & 9.8 & 2.5 \\
\hline
\end{tabular}

Table 3 showed the percentages of the academic indicators' statements:

11. The eleventh Statement: (59.0\%) respondents agreed with it, and (31.8\%) were neutral. Nevertheless, simultaneously, $(9.1 \%)$ respondents disagreed with this statement.

12. The twelfth Statement: $(57.2 \%)$ of the respondents agreed with it, and $(32.7 \%)$ were neutral. In contra $(16.3 \%)$ respondents disagreed with the statement.

13. The thirteenth Statement: (40.0\%) of the respondents agree with it, and (33.6\%) were neutral. In contrast, (26.4\%) respondents disagreed with this statement.

14. The fourteenth Statement: (49.1\%) respondents agreed with it, and (34.5\%) were neutral. In comparison, $(16.3 \%)$ respondents disagreed with this statement.

15. The fifteenth Statement: (38.2\%) respondents agreed with it, and (34.5\%) were neutral. In contrast, (17.2\%) respondents disagreed with this statement.

16. The sixteenth Statement: (60.0\%) respondents agreed with it, and (33.6\%) were neutral. In comparison, $(6.4 \%)$ respondents disagreed with this statement.

17. The seventeenth Statement: (61.8\%) respondents agreed with it, and (31.8\%) were neutral. In comparison, (6.4\%) respondents disagreed with this statement. 
18. The eighteenth Statement: (55.4\%) respondents agreed with it, and (30.0\%) were neutral. Simultaneously, $(14.6 \%)$ respondents disagreed with this statement.

19. Nineteenth Statement: (50.9\%) respondents agreed with it, and (37.3\%) were neutral. In comparison, $(11.8 \%)$ respondents disagreed with this statement.

20. Twentieth Statement: (63.6\%) respondents agreed with it, and (28.2\%) were neutral. In contrast, (8.2\%) respondents disagreed with this statement.

To conclude, regarding the participants' responses to the first question: What were the Blended learning benefits on the English-major pre-service teachers' academic performance? (55.7\%) respondents strongly agree with it, and (32.0\%) were neutral. In contrast, (12.3\%) respondents disagreed.

\subsubsection{Environmental Indicators' Results}

The following are the frequency distribution and percentage of the first indicator's statements that answered the study's second question: How did English-major pre-service teachers evaluate the Blended learning environment's effectiveness in their engagement and interaction?

Table 4. Descriptive Statistics for Environmental Indicators

\begin{tabular}{|c|c|c|c|c|c|c|}
\hline Statements & & $\begin{array}{l}\text { Strongly } \\
\text { agree }\end{array}$ & Agree & Neutral & Disagree & Strongly disagree \\
\hline \multirow{2}{*}{$\begin{array}{l}\text { 1. I was highly motivated through blended } \\
\text { learning environment. }\end{array}$} & $\mathrm{F}$ & 20 & 0 & 38 & 10 & 2 \\
\hline & $\%$ & 18.8 & 36.4 & 34.5 & 9.1 & 1.8 \\
\hline \multirow{2}{*}{$\begin{array}{l}\text { 2. I like teachers' non-verbal expressions like } \\
\text { eye contact, facial expressions, and } \\
\text { gestures through face-to-face classes. I feel } \\
\text { closer. }\end{array}$} & $\mathrm{F}$ & 25 & 47 & 29 & 9 & - \\
\hline & $\%$ & 22.7 & 42.7 & 26.4 & 8.2 & - \\
\hline \multirow{2}{*}{$\begin{array}{l}\text { 3. Blended learning helped me and my } \\
\text { classmates to regularly evaluate each } \\
\text { other. }\end{array}$} & $\mathrm{F}$ & 12 & 44 & 38 & 14 & 2 \\
\hline & $\%$ & 10.9 & 40.0 & 34.5 & 12.7 & 1.8 \\
\hline \multirow{2}{*}{$\begin{array}{l}\text { 4. Engagement, motivation, and interaction } \\
\text { through BL learning were the factors that } \\
\text { enhanced my success. }\end{array}$} & $\mathrm{F}$ & 12 & 52 & 33 & 11 & 2 \\
\hline & $\%$ & 10.9 & 47.3 & 30 & 10 & 1.8 \\
\hline \multirow{2}{*}{$\begin{array}{l}\text { 5. Online classes were less annoying than the } \\
\text { traditional ones. }\end{array}$} & $\mathrm{F}$ & 22 & 39 & 28 & 19 & 2 \\
\hline & $\%$ & 20 & 35.5 & 25.5 & 17.3 & 1.8 \\
\hline \multirow{2}{*}{$\begin{array}{l}\text { 6. Online classroom activities made me feel } \\
\text { less involved. }\end{array}$} & $\mathrm{F}$ & 18 & 43 & 3 & 17 & 1 \\
\hline & $\%$ & 16.4 & 39.1 & 28.4 & 15.5 & 0.9 \\
\hline \multirow{2}{*}{$\begin{array}{l}\text { 7. BL trained me in a new interactive } \\
\text { learning methodology. }\end{array}$} & $\mathrm{F}$ & 15 & 46 & 40 & 9 & - \\
\hline & $\%$ & 13.6 & 41.8 & 36.4 & 8.2 & - \\
\hline
\end{tabular}

Table 4 explains the percentage of the second hypothesis (Environmental Indicators) as:

1. The first statement: $(54.6 \%)$ of the respondents agree with it, and (34.5\%) are neutral. In contrast, $(0.9 \%)$ of the respondents disagree with the first statement.

2. The second statement: (65.4\%) of the respondents agree with it, and (26.4\%) are neutral. In contrast, $(8.2 \%)$ of the respondents disagree with the second statement.

3. The third statement: $(50.9 \%)$ of the respondents agree with it, and (34.5\%) were neutral. In contrast, (14.5\%) respondents disagreed with this statement.

4. The fourth statement: (58.2\%) respondents agreed with it, and (30.0\%) were neutral. In contrast, only $(11.8 \%)$ respondents disagree with this statement.

5. The fifth statement: $(55.5 \%)$ of the respondents agreed with it, and $(25.5 \%)$ were neutral, whereas (19.0\%) respondents disagreed with this statement.

6. The sixth Statement: (55.5\%) of the respondents agreed with it, and 28.2\%) were neutral. In contrast, $(16.4 \%)$ respondents disagreed with this statement.

7. The seventh Statement: (55.4\%) respondents agreed with it, and (36.4\%) were neutral. In contrast, (8.2\%) respondents disagreed with this statement 
Table 5. Descriptive statics for Environmental Indicators

\begin{tabular}{|c|c|c|c|c|c|c|}
\hline Statements & & $\begin{array}{c}\text { Strongly } \\
\text { agree }\end{array}$ & Agree & Neutral & Disagree & $\begin{array}{l}\text { Strongly } \\
\text { disagree }\end{array}$ \\
\hline \multirow{2}{*}{$\begin{array}{l}\text { 8. I felt isolated during online courses, unlike } \\
\text { face-to-face ones. }\end{array}$} & $\mathrm{F}$ & 18 & 46 & 27 & 15 & 4 \\
\hline & $\%$ & 16.4 & 41.8 & 24.5 & 13.6 & 3.6 \\
\hline \multirow{2}{*}{$\begin{array}{l}\text { 9. Blended learning eased my connection during } \\
\text { my off days. }\end{array}$} & $\mathrm{F}$ & 20 & 49 & 28 & 12 & 1 \\
\hline & $\%$ & 18.2 & 44.5 & 25.5 & 10.9 & 0.9 \\
\hline \multirow{2}{*}{$\begin{array}{l}\text { 10. Blended learning provided me with feedback } \\
\text { from my peers and teachers on my } \\
\text { performance. }\end{array}$} & $\mathrm{F}$ & 17 & 44 & 36 & 10 & 3 \\
\hline & $\%$ & 15.5 & 40.0 & 32.7 & 9.1 & 2.7 \\
\hline \multirow{2}{*}{$\begin{array}{l}\text { 11. Blended learning chat rooms encouraged me } \\
\text { to discuss topics covered previously in the } \\
\text { traditional classes. }\end{array}$} & $\mathrm{F}$ & 17 & 48 & 33 & 12 & - \\
\hline & $\%$ & 15.5 & 43.6 & 30.0 & 10.9 & - \\
\hline \multirow{2}{*}{$\begin{array}{l}\text { 12. Blended learning interactive tools enhanced my } \\
\text { learning input and output. }\end{array}$} & $\mathrm{F}$ & 13 & 49 & 37 & 9 & 2 \\
\hline & $\%$ & 11.8 & 44.5 & 33.6 & 8.2 & 1.8 \\
\hline \multirow{2}{*}{$\begin{array}{l}\text { 13. I would to take blended learning courses in the } \\
\text { future. }\end{array}$} & $\mathrm{F}$ & 19 & 44 & 31 & 12 & 4 \\
\hline & $\%$ & 17.3 & 40.0 & 28.2 & 10.9 & 3.6 \\
\hline \multirow{2}{*}{$\begin{array}{l}\text { Q2: How do English-major pre-service teachers evaluate } \\
\text { the Blended learning environment's effectiveness in their } \\
\text { engagement and interaction? }\end{array}$} & $\mathrm{F}$ & 228 & 551 & 401 & 159 & 23 \\
\hline & $\%$ & 16.7 & 40.5 & 29.4 & 11.7 & 1.7 \\
\hline
\end{tabular}

Table 5 showed the following:

8. The Eighth Statement: $(58.2 \%)$ of the respondents agree with it, and $(24.5 \%)$ were neutral. In contrast, $(17.2 \%)$ respondents disagreed with this statement.

9. The Ninth Statement: $(62.7 \%)$ respondents agreed with it, and (25.5\%) were neutral. In contrast, $(11.8 \%)$ respondents disagreed with this statement.

10. The Tenth Statement: $(55.5 \%)$ respondents and agreed with it, and (32.7\%) were neutral. In comparison, $(11.8 \%)$ respondents disagreed with this statement.

11. The Eleventh statement: $(59.1 \%)$ respondents agreed with it, and (30.0\%) were neutral. However, at the same time, $(10.9 \%)$ respondents disagreed with this statement.

12. The Twelfth Statement: $(56.3 \%)$ of the respondents agree with it, and (33.6\%) were neutral. In comparison, $(10.1 \%)$ of the respondents disagreed with this statement.

13. The Thirteenth Statement: $(57.3 \%)$ of the respondents agreed with it, and (28.2\%) were neutral. In contrast, $(14.5 \%)$ of the respondents disagreed with this statement.

To conclude, the second question asked about the environmental Indicators: (How did English-major pre-service teachers evaluate the Blended learning environment's effectiveness in their engagement and interaction? (57.2\%) respondents agreed with it, and (29.4\%) were neutral. In contrast, (13.4\%) respondents disagreed.

\subsection{Qualitative Results from the Written Essays}

Responses presented below were generated from the informative essays' contents analysis written by thirty-eight of the purposive sample group, entitled "The virtual classes and the student's academic success. Below is a summary of the students' opinions that answered the study's three questions.

\subsubsection{Results Answering the First Question}

The following are the participants' written reflections that answered the study's first question: What were the Blended learning benefits on the English-major pre-service teachers' academic performance?

The Purposive Group Reflection on the Blended Learning Benefits:

\section{The Blended learning}

a)saved the continuity of the academic year 2020-2021 without taking the risk of COVID-19's infection, and guarantee the students' academic success, b) has powerful tools not found in the physical space, and it paved the way to the students' success, c) it made the courses flexible, easy, fast, and enjoyable, d) it enabled a better understanding through online activities and participation, e) allowed instant feedback and instant grading, f) diverted learning methods, g) videos, texts, projects, presentations, discussions, helped us to absorb the content easily, h) facilitated obtaining the courses' materials, i) it eased the course works' evaluation through different fair online methods, j) the online tests' grades were fairer than papers- pens' tests, k) helped the students to be more productive by managing 
and allocating extra time to do other extra urgent tasks, 1) it was an evidence of a good indication for running a better education in our region, $\mathrm{m}$ ) It eased the formation of virtual groups' discussions.

Overall, the participants shared positive opinions on their academic progress towards blended learning.

4.2.2 Results Answering the Second Question

The participants' written reflections answered the second question: How do English-major pre-service teachers evaluate the Blended learning environment's effectiveness in their engagement and interaction?

The responses show that the blended learning environment was: a) feasible in saving time and money spent preparing the traditional courses' projects, assignments, and daily university costs. b) It allowed reviewing the recorded lectures or taking exams anywhere. c) it replaced the papers' pens' tasks with phones, tablets, or computers. d) It reduced the geographical distance that helped manage cost and time freely e) had an observable change in the students' bad health habits by buying the university's expensive junk foods and beverages. $\mathrm{f}$ ) enhanced the collaboration and communication between the students and teachers. g) reached a vast number of students at the different zones, $h$ ) protected shy students, and encouraged them to ask questions and engage in online discussions. i) allowed the students, who had a part-time job, to attend classes from their workplace, j) enabled them to highlight the essential points and study more than usual.

Overall, the students' agreed that blended learning's environment had significant impacts on increasing the number of engagements and interactions, which positively correlated with their academic performance.

\subsubsection{Results Answering the Third Question Concerning the Obstacles}

The following is a summary generated from the participants' written reflections toward the blended learning challenges, which answer the study's third question: What obstacles did the English- major pre-service teachers face in the blended learning courses?

a) the blended learning virtual classes lacked supervision and consultation, b) it required computers and a stable internet connection, and some students do not have, c) it could not control over students' total attendance; and finally, d) the physical absence of the teachers made it difficult for some students to concentrate well.

All responses focused on the instructors' physical absence, which led to a lack of concentration and actual attendance among some irresponsible students. In some cases, as reflected by a few participants, they were experienced the followings a) missed the energetic and warm climate of face-to-face courses, b) missed instructor's body language and nonverbal signals, c) the physical absence of their educators drove the participants to lose consideration., finally, d) some online courses lack administration, eagerness, and motivation.

\section{Study Limitations}

The researcher believes no study is perfect. Therefore, this study tried to avoid sampling errors that led to shortcomings and designed the qualitative and quantitative methodology in a simple random sampling that covered a wide range of respondents. These influenced positively the interpretation of the results of the study.

\section{Discussion}

The present study explored and assessed the students' perceptions and reflections toward blended learning's useful, easy, clear, feasible tools and supported environments on their academic success, interactions, and engagement. The questionnaire and the essays written by the purposive sample answered the study's three questions. The results indicated that:

1. The blended learning courses facilitated encouraged them to download materials, upload assignments, carry out online examinations, and encourage the participants to engage in discussions, asking or answering questions their instructors and classmates raised.

2. Blended learning environment developed their EFL four skills' interaction.

3. Helped them move beyond the traditional learning methods and take part in the learning processes

4. It paved the way for them to acquire the skills needed for their future career. See appendixes' links (1) and essays' samples.

Moreover, the quantitative and qualitative results show that blended learning is a beneficial approach to diversifying teaching methods and positively affects learning inputs and outputs.

Furthermore, the study agreed with (Napier \& Smith, 2009) that the blended learning helped the participants be 
independent learners and achieve higher grades. They showed positive and vigorous agreements on most blended learning academic and environment indicators. For instance, students feel more comfortable interacting with classmates during virtual classes than face-to-face ones. In addition, the instant feedback inside the virtual courses helped them to correct their mistakes.

The findings agree, support, and go in one line with Millar's theory (2014), Nazarenkoa (2015), Albiladi \& Khlood (2019), and Bakeer (2018) that most of the participants were favorable the blended learning format. However, the study contrasts with some responses that believed combined learning wastes time, is easy to cheat in exams, and creates social isolation. The results of the current study contrast with Ja'ashan's study (2015) from Saudi Arabia, in which the students saw traditional learning as active as blended learning. Whereas the survey agreed with the results reached by Fathelrahman (2018) from King Faisal University, Alhasa, KSA, that feedback from the students could improve the teaching quality of distance learning, which leads to students' better understanding, the thing that employed by the current study.

Concerning the obstacles, most participants agreed upon item four in the electronic survey, which attracted the researcher's attention; it rated (74.3\%) regarding the blended learning environment's impact on interaction and collaboration.

Unlike the traditional classroom's warm climate, the participants stated they encountered emotional deprivation during virtual courses; they missed the non-verbal expressions, body language, eye contact, and non-verbal message exchange with our teachers during the face-to-face classes. They also complained about the unstable internet connection in their geographical area. Some stated that the absence of teachers' control made some students lose concentration during lectures. Others indicated that they chose the BL course because it was the only one that fitted their schedule. Few students assumed that the virtual classes lacked supervision to control students' actual attendance.

To conclude, the results answered the research questions that blended learning met their academic performance expectations, success, built their EFL skills, eased engagement, individual reflection, or group presentations. It was less annoying, facilitating the interaction. Chat rooms encouraged them to incorporate materials from the discussion.

\section{Conclusion}

The blended learning system increased the participants' academic performance through useful, easy, flexible, clear, and feasible tools. Its comfortable environment increased the participants' interaction, engagement, collaboration, and communication skills. They also became more self-regulated, self-dependents, friendly, and confident. In addition, it enables them to build strong relationships with their classmates and instructors.

The researcher observed a significant satisfaction among the participants toward the blended learning tools, which enabled them to record sessions for later reviewing, usefulness, clarity and, feasibility that encouraged long-term learning. At the same time, there was a bit, negative emotional feeling regarding their instructors' absolute physical absence and the lack of warm face-to-face interaction. Finally, integrating blended learning in the academic program enables the university to reach the most distinguished and prominent ranks.

\section{Implication and Gaps Filling}

Investigating the impact of blended learning and its environment on English-major pre-service teachers' collaboration and academic performance puts the study among the research that highlights the roles of technology in advancing knowledge and empowering learners' mental, cognitive, and social forms.

Furthermore, the study sought to collaborate with the previous studies by conducting more future research to explore the different viewpoints of blended learning users, which motivated the current research to move the existing investigation forward. Few studies have examined, described, and assessed the significant impact of blended learning on students' academic performance using questionnaires supported by written essays. The participants informatively expressed their attitudes freely toward the effects of integrating blended learning to enhance teaching and learning delivery.

\section{Recommendations}

The researcher recommends the blended learning instructors to: a) support, inspire and encourage the students to feel friendly; b) create a dynamic environment, give more elements of the course, and monitoring it too; c) encourage the students to be open up by spending few minutes at the beginning of a blended learning class, to engage in ice-breaking subjects to create a warm and inviting atmosphere.

The study suggests investigating the correlation between the students' psychological and emotional status with their 
academic progress for future research.

Concerning the obstacles, most participants agreed upon one item in the electronic survey, which attracted the researcher's attention, the fourth item. It rated (74.3\%) the Blended learning environment's impact on interaction and collaboration.

The participants stated that they encountered emotional separation during virtual courses, unlike the traditional classroom's warm climate. In addition, they added, "We missed the non-verbal expressions, body language, eye contact, and non-verbal message exchange with our teachers during the face-to-face classes." They faced an unstable internet connection in their geographical area. Some stated that the absence of teachers' control made some students lose concentration during lectures. Others indicated that they chose blended learning because it was the only one that fitted their schedule.

\section{Acknowledgement}

The author extends her appreciation to the Deanship of Scientific Research at Majmaah University for supporting this work research under grant No. 94/1439. Thankfulness goes to my brother Eng. Abdulwahab Elhussein for his precious technical support and to the participants who willingly participated in this research.

\section{References}

Akbarov, A., Gonen, K., \& Aydogan, H. (2018). Students' Attitudes toward Blended Learning in EFL Contexts. Acta Didactica, Napocensia, 11(1). https://doi.org/10.24193/adn.11.1.5

Albiladi, W. S., \& Khlood, K. A. (2019). Blended Learning in English Teaching and Learning: A Review of the Current Literature. Journal of Language Teaching and Research, 10(2), 232-238. https://doi.org/10.17507/j1tr.1002.03

Allen, I. E., \& Seaman, J. (2011). Going the distance: Online education in the United States. The Online Learning Consortium. Retrieved from http://sloanconsortium.org/publications/survey/going_distance_2011

Bakeer, A. M. (2018). Students' Attitude towards Implementing Blended Learning in Teaching English in Higher Education Institutions: A Case of Al-Quds Open University. International Journal of Humanities and Social Science, 8(6). https://doi.org/10.30845/ijhss.v8n6a15

Bakerson, M., Trottier, T., \& Mansfield, M. (2015). The Value of Embedded Formative Assessment: An Integral Process in Online Courses.

Bowyer, J. (2017). Blending Learning: Bringing the Elements Together. Research Matters: A Cambridge Assessment Publications. Retrieved from http://www.cambridge assessment.org.uk/research-matter

Fathelrahman, A. (2018). Using Reflection for Improving Distance Learning Course Delivery: A Case of Teaching Management Information Systems Course. The Journal of Open, Distance, and e-Learning. https://doi.org/10.1080/02680513.2018.1508338

Garrison, D. R. (2005). Learning Collaboration Principles. Paper presented for the Sloan-C Summer Workshop, Victoria, BC, Canada, 2005. https://doi.org/10.5539/elt.v8n9p40

Grassmeyer, D., Dibbs, R., \& Jensen, T. (2011). Determining utility of formative assessment through virtual community: Perspectives of online graduate students. The Quarterly Review of Distance Education, 12(1), 23-35.

Hancock, T., Smith, S., Timpte, C., \& Wunder, J. (2010). PALs: Fostering Student Engagement and Interactive Learning. Journal of Higher Education Outreach and Engagement, 14(4), 37.

Innes, M. C., Norman D. V., \& Garrison, R. D. (2013). Teaching in Blended Learning Environments: Creating and Sustaining ..Pub. AU Press, Athabasca University.

Ja'ashan, M., \& N., H., M (2015), Perceptions and Attitude towards Blended Learning for English Language Courses. A case Study of Students at the University of Bisha. English Language Teaching, 8(9).

Jobe, W. (2011). HIVE (Hypermedia Interactive Virtual Environment) - Utilizing HTML5 and instructional design to improve online learning. Paper presented at the Society for Information Technology \& Teacher Education International Conference 2011. Retrieved from http://www.editlib.org/p/36820

Koc, S., Liu, X., \& Wachira, P. (2015). Assessment in Online and Blended Learning Environment. Information Age Publishing. Inc. The USA. 
Lalima \& Dangwal, K. L. (2017), Blended Learning: An Innovative Approach. Universal Journal of Educational Research, 5(1), 129-136. https://doi.org/10.13189/ujer.2017.050116

Lim, C. P., \& Wang, L. B. (Eds.) (2016). Blended Learning for Quality Higher Education: Selected Case Studies on Implementation from Asia-Pacific. Paris, France: UNESCO.

Liu, X. J., Magjuka, R., Bonk, C. J., \& Lee, S. H. (2007). Does a sense of community matter? An examination of participants' perceptions on building learning communities in online courses. The Quarterly Review of Distance Education, 8(1), 9-24.565-9. Paris, France.

Marquardt, S. K. (2011). (Re)telling: A narrative inquiry into pre-service TESOL teachers' study abroad experiences (Unpublished doctoral dissertation). Michigan State University, Ann Arbor, MI. ERIC Number: ED533232, ISBN: ISBN-978-1-1248-5886-9.

Michael, B. H., Staker, H., \& Clayton, N. C (2014), Blended: Using Disruptive Innovation to Improve Schools 1st Edition. Library of Congress, USA.

Miller, M. D. (2014). Minds Online: Teaching Effectively with Technology. Harvard University Press. London, England. https://doi.org/10.4159/harvard.9780674735996

Napier, N. P., \& Smith, S. (2009). Assessing Blended Learning: Student Outcomes and Perceptions. Presented at Americas Conference on Information Systems, San Francisco, California.

Nazarenkoa, A. L. (2015). Blended Learning vs. Traditional Learning: What Works? (A Case Study Research). Procedia - Social and Behavioral Sciences, 200(2015), 77-82. https://doi.org/10.1016/j.sbspro.2015.08.018

OECD. (2016). Innovating Education and Educating for Innovation: The Power of Digital Technologies and Skills. OECD Publishing, aris. https://doi.org/10.1787/9789264265097-en

Okaz, A. (2015). Integrating Blended Learning in Higher Education: Procida: Social and Behavioral Science. https://doi.org/10.1016/j.sbspro.2015.04.086

Siregar, N., Siregar, T. M., \& Siregar, B. H. (2019). Blended learning in students' views. IOP Conf. Series: Journal of Physics: Conference Series. https://doi.org/10.1088/1742-6596/1188/1/012099

Tang, C. M., \& Chaw, L. Y. (2013). Readiness for Blended Learning: Understanding Attitude of University Students. International Journal of Cyber Society Education, 6(2), 79-100. https://doi.org/10.7903/ijcse.1086

Tomlinson, B., \& Whittaker, C. (Eds.). (2013). Ed, Blended Learning in English, Language Teaching: Course Design and Implementation. British Council, 2013 Brand and Design/D057. 10 Spring Garden London SW1A 2BN, UK.

Tucker, C. R., Wycoff, T., Green, J. T. (2016). Blended Learning in Action: A Practical Guide Toward Sustainable Change (Corwin Teaching Essentials). SAGE -Crown Press. Delhi, India.

Tucker, K. R. (2019). Power Up Blended Learning: A Professional Learning Infrastructure to Support Sustainable Change (Corwin Teaching Essentials). 1st Edition. SAGE Production, USA.

Tylor, J. S., Bogdan, R., \& M., DeVault, L. (2016). Introduction to Qualitative Research Methods- a Guidebook and Resource $4^{\text {th }}$ ed. Published by John Wiley \& Sons, Inc., Hoboken, New Jersey.

Wei, Y., Shi, Y., Yang, H. H., \& Liu, J. (2017). Blended Learning versus Traditional Learning: A Study on Students' Learning Achievements and Academic Press". A Conference Paper. https://doi.org/10.1109/ISET.2017.57

Appendix (1) The Survey link:

https://docs.google.com/forms/d/1sXQMXmCyTG78CzFYIejtt9GqBT_wEdLwgzzK_E-uBfk/edit

\section{Copyrights}

Copyright for this article is retained by the author(s), with first publication rights granted to the journal.

This is an open-access article distributed under the terms and conditions of the Creative Commons Attribution license (http://creativecommons.org/licenses/by/4.0/). 